\title{
Chemical identification of Tagetes minuta Linnaeus (Asteraceae) essential oil and its acaricidal effect on ticks
}

\author{
Caracterização química e efeito acaricida do óleo essencial de \\ Tagetes minuta Linnaeus (Asteraceae) em carrapatos
}

\author{
Marcos Valério Garcia ${ }^{1}$; Jaqueline Matias ${ }^{1}$; Jacqueline Cavalcante Barros ${ }^{1}$; Dênis Pires de Lima ${ }^{2}$; \\ Rosângela da Silva Lopes²; Renato Andreotti ${ }^{1 *}$ \\ ${ }^{1}$ Animal Health Laboratory, Embrapa Beef Cattle, Campo Grande, MS, Brazil \\ ${ }^{2}$ LP4 Laboratory, Centre for Science and Technology, Universidade Federal do Mato Grosso do Sul - UFMS, \\ Campo Grande, MS, Brazil
}

Received September 12, 2012

Accepted October 15, 2012

\begin{abstract}
The control of tick species that affect animal production is vital for the economic welfare of the cattle industry. This study focused on testing the acaricidal activity of the essential oil from the leaves and stems of Tagetes minuta against several Brazilian tick species, including Rhipicephalus (Boophilus) microplus, Rhipicephalus sanguineus, Amblyomma cajennense and Argas miniatus. The chemical composition of the essential oil was determined by chromatography and spectroscopy analyses, which revealed the presence of monoterpenes. The adult immersion test (AIT) and the larval packet test (LPT) were used to evaluate the efficacy of T. minuta essential oil in tick management at concentrations of 2.5, 5, 10, 20 and 40\%. The results demonstrated that the T. minuta essential oil had over $95 \%$ efficacy against four species of ticks at a concentration of $20 \%$. These results suggest that the essential oil of $T$. minuta could be used as an environmentally friendly acaricide.
\end{abstract}

Keywords: Tagetes minuta, ticks, phytotherapy, control.

\section{Resumo}

O controle de carrapatos que causa impacto na produçáo de bovinos possui importância econômica para a cadeia produtiva. Neste trabalho objetivou-se testar a atividade acaricida do óleo essencial das folhas e caules de Tagetes minuta contra várias espécies de carrapatos brasileiros, incluindo Rhipicephalus (Boophilus) microplus, Rhipicephalus sanguineus, Amblyomma cajennense e Argas miniatus. A composição química do óleo foi determinada por GC-MS e análises de espectroscopia de RMN, que revelaram a presença de monoterpenos. Na avaliaçáo destas substâncias no controle do carrapato foram empregados os testes de imersão de adulto (TIA) e o de pacote de larvas (TPL) para o extrato de óleo de T. minuta nas concentraçóes de 2,5\%; 5\%; 10\%; 20\% e 40\%. Os resultados do TPL e TIA demonstraram que o óleo essencial na concentração de $20 \%$ de T. minuta apresenta eficácia superior a $95 \%$ nas quatro espécies de carrapato. Estes resultados sugerem que o óleo essencial de $T$. minuta pode ser usado como um acaricida eficaz e com baixo impacto ambiental.

Palavras-chave: Tagetes minuta, carrapatos, fitoterápico, controle.

\section{Introduction}

Ticks are ectoparasites that affect an extensive range of vertebrate hosts and transmit a wide variety of pathogens. They are the most common external parasites of economic importance in livestock production worldwide. Chemical acaricides have been developed to control ticks and are applied as dips, sprays and pour-ons at various application intervals.

\footnotetext{
*Corresponding author: Renato Andreotti

Animal Health Laboratory, Embrapa Beef Cattle, Av. Radio Maia, 830,

Vila Popular, Campo Grande, MS, Brasil

e-mail: andreotti@cnpgc.embrapa.br
}

There are approximately 61 species of ticks in Brazil (BARROSBATTESTI et al., 2006). The four species examined in this study represent the ticks that are important in cattle and poultry production and environmental and public health.

There is a considerable economic incentive to control the ticks that affect animal production systems. In Brazil, the annual economic loss in the cattle industry attributed to Rhipicephalus (B.) microplus has been estimated at US $\$ 2$ billion (GRISI et al., 2002). Over 170 million bovines are managed by the Brazilian cattle industry (ANUALPEC, 2009), and the Brazilian parasiticide 
market has a value of US $\$ 960$ million in sales, which accounts for $34 \%$ of the Brazilian veterinary product market (SINDAN, 2010).

Rhipicephalus sanguineus is the primary tick species found on dogs in the urban areas of Brazil (SZABÓ et al., 2001); Amblyomma sp. are also found on dogs in rural areas (LABRUNA; PEREIRA, 2001). Amblyomma cajennense is the primary tick species found on horses and has also been recovered from dogs (LABRUNA et al., 2000).

Argas miniatus Koch (1844) is a tick that affects poultry and other birds. It can cause productivity losses and transmit pathogenic agents (LISBÔA et al., 2008).

According to the criteria of the Brazilian Ministry of Agriculture and Food Supply, new tick control products must display an efficacy of at least $95 \%$ to be registered. However, an official program for tick control is lacking, and the producers largely define the criteria for tick control. The development of acaricide resistance in ticks continues to be a major driver of new anti-parasitic drug development (ANDREOTTI et al., 2011).

There has been an increase in the amount of research focused on the use of plant extracts for the control of parasites. For example, the oil from neem (Azadirachta indica) seeds was evaluated and shown to possess acaricidal properties, such as an inhibitory effect on vitellogenin during the oogenesis of arthropods (WILLIAMS, 1993; KALAKUMAR et al., 2000).

Tagetes minuta is an annual perennial herb that belongs to the Asteraceae family. Its leaves are slightly glossy, green and pinnately dissected into 4 to 6 pairs of pinnae (PRAKASA et al., 1999). This plant is used in popular medicine and grows in temperate regions of South America (MOYO; MASIKA, 2009). Previously, Moghaddam et al. (2007) showed that the main components of T. minuta oil are $\alpha$-terpineol, (Z)- $\beta$-ocimene, dihydrotagetone, (E)-ocimenone, $(\mathrm{Z})$-tagetone, and (Z)-ocimenone; the composition was confirmed in this study.

Volatile oils are plant products made by heating with water vapor. These attractive or repellent substances of plants are mainly terpenic in nature, of low molecular weight, and volatile. Such substances are usually referred to as aromatic essential oils, and they accumulate in all plant organs (KNAAK; FIUZA, 2010).

Essential oils are the steam-distilled fraction of the plant, and they are liquid at ambient temperature (ENAN, 2001). The composition of the essential oil of $T$. minuta varies by the part of the plant and its growth stage, but it is consistent at all geographical locations. In the province of Chaco, dihydrotagetone levels reach a maximum of $42.9 \%$ in the leaves of non-bloomed plants, and $\beta$-ocimene and tagetenone levels reach a maximum of $45.4 \%$ and $32.9 \%$, respectively, in the flowers (CHAMORRO et al., 2008).

T. minuta has been shown to be antimicrobial (SOUZA et al., 2000), insecticidal and acaricidal (TOMOVA et al., 2005; MOYO; MASIKA, 2009). The terpenes in the T. minuta oil are toxic to mosquitoes (MACÊDO et al., 1997) and have been reported to have aphicidal properties (TOMOVA et al., 2005).

The purpose of this study was to characterize the essential oil of Tagetes minuta by GC-MS analysis and to evaluate its acaricidal properties against four species of Brazilian ticks.

\section{Materials and Methods}

\section{Study site}

The study was conducted in Campo Grande-MS, Brazil, located at $20^{\circ} 26^{\prime} \mathrm{S}$ and $54^{\circ} 42^{\prime} \mathrm{W}$ at $520 \mathrm{~m}$ above sea level.

\section{Plant material and extraction}

The leaves and stems of Tagetes minuta were collected from the garden, dried at $40{ }^{\circ} \mathrm{C}$ for 72 hours and ground in a grinder with a $5-\mathrm{mm}$ mesh. A total biomass of $1 \mathrm{~kg}$ was submitted to steam distillation to extract $185 \mathrm{~mL}$ of essential oil. The herbage was placed on a perforated plate, which served as a support to homogenize the steam flow. The plate was then placed on an extractor, and a pipe (gooseneck) was attached to transfer the vapors to a condenser.

The steam carried the volatile organic compounds (essential oil) that were present in the plant material into the vapor phase. A container was placed at the end of the condenser to separate the essential oil from the water. The process lasted 2 hours inside an extractor at normal atmospheric pressure and $96-97^{\circ} \mathrm{C}$. The residual water from the essential oil isolation was removed by filtration with anhydrous sodium sulfate. The essential oil was stored in amber flasks.

\section{Oil extract chromatography (GC-MS)}

The essential oil extract was analyzed qualitatively and quantitatively using a Shimadzu GCMS-QP2010 Plus equipped with an Rtx-WAX Crossbond-Carbowax-polyethylene glycol column (30 $\mathrm{m} \times 0,25 \mathrm{~mm}$ i.d. $\times 0,25 \mu \mathrm{m}$ film thickness), a split injector, a ratio of 50:1, an automatic injection system and a selective mass detector. The test was performed at $250^{\circ} \mathrm{C}$, and the oven temperature was programmed to increase from 50 to $210{ }^{\circ} \mathrm{C}$ at $10{ }^{\circ} \mathrm{C} / \mathrm{min}$ using $\mathrm{He}$ as the carrier gas. The gas flow was $0.7 \mathrm{~mL} / \mathrm{min}$ at a constant speed of $30 \mathrm{~cm} / \mathrm{s}$ and an interface of $250{ }^{\circ} \mathrm{C}$. The injector temperature was $200{ }^{\circ} \mathrm{C}$, and the injection volume was $1.0 \mu \mathrm{L}$. The sample was prepared in $\mathrm{CHCl}_{3}$. The peak area percentages were calculated without correction factors or internal standards. The peaks were identified by comparison of their mass spectra (MS) to the mass spectral data from the National Institute of Standards and Technology (NIST) and Wiley's FFNSC (Flavor and Fragrance Natural and Synthetic Compounds) based on an analysis of the fragmentation pattern obtained for each component and on a comparison of their retention indexes (IR) with the Shimadzu GCMS Solution Program, version 2.53.

\section{NMR spectroscopy}

The NMR spectra were recorded on a Bruker Avance DPX-300 instrument equipped with a $5-\mathrm{mm}$ direct probe with $\mathrm{z}$-gradient field. The ${ }^{1} \mathrm{H}$ and ${ }^{13} \mathrm{C}$ NMR spectra (at 300 and $75 \mathrm{MHz}$, respectively) were measured at a temperature of $300 \mathrm{~K}$ using $10 \mathrm{mg} \cdot \mathrm{mL}^{-1}$ in $\mathrm{CDCl}_{3}$ solvent. Tetramethylsilane was used as an internal reference. 
The chemical shifts are provided on the $\delta$ scale. The experiments were performed using standard pulse sequences, as suggested by the equipment manufacturer.

\section{Bioassay}

The engorged female ticks, including $R$. (B.) microplus, $R$. sanguineus, $A$. cajennense and $A$. miniatus, were collected from naturally infested animals in Campo Grande-MS. The animals were free of acaricide treatments for 45 days prior to tick collection. The ticks were previously diagnosed as resistant to acaricide families, including pyrethroid (SP), organophosphate (OP) and amitraz (Am).

The engorged female ticks were washed with water and dried with paper towels. A group of females was used in an adult immersion test (AIT), and another group was incubated at $27 \pm 1.5^{\circ} \mathrm{C}$ and $70-80 \%$ relative humidity (DRUMMOND, 1973) for two weeks until their eggs were laid. These eggs provided the larvae for the larval packet test (LPT) (FAO, 1984).

\section{Adult immersion test}

The AIT (DRUMMOND, 1973) was used to test the acaricidal activity of the T. minuta crude extracts (leaf and stem), neem oil and acaricides on adult ticks. Ten engorged female ticks of each species were deposited into a petri dish. The tick groups were immersed in T. minuta oil extract or neem oil at concentrations of $2.5,5,10,20$ and $40 \%$.

Tween $20(2 \%)$ was used to solubilize the essential oil and neem oil in water. A concentration curve was performed to define the optimal concentration of Tween 20 that enabled a stable aqueous solution.

For the established acaricides, the commercially recommended concentrations were evaluated. The assays were performed in triplicate.

The treated groups were immersed for five minutes in diluted crude extract with $2 \%$ Tween 20 , and the control group was immersed in distilled water with $2 \%$ Tween 20 , as recommended in a preliminary study (ROSADO-AGUILAR et al., 2008). The ticks were individually plated in a 24-well plate and were incubated for 15 days at the conditions described above. The ticks were analyzed with a stereomicroscope, and the mortality rate and the weight of the eggs produced by each group were recorded.

The mortality rate was recorded daily. The dead ticks were recognized by the presence of cuticular darkness, hemorrhagic skin lesions, a lack of Malpighian tubes and stillness. After 15 days, the number of females laying eggs was recorded, and the eggs of each group were weighed using an analytical scale. Fifty eggs of each batch were placed in $25 \times 95-\mathrm{mm}$ glass vials, maintained in conditions similar to those in which the adult ticks were maintained and observed for 21 days. The hatching rates of the eggs were then estimated, and they were compared to the control group and the other experimental groups. The percent inhibitions of egg laying and larval hatching were determined for all of the groups (CEN-AGUILAR et al., 1998)

\section{Larval packet test}

The LPT was used to test the acaricidal activity of the crude extracts (leaf and stem) against the four species of tick larvae (FAO, 1984). Tween 20 was diluted with distilled water to a concentration of $2 \%$ and was used to dilute the plant extracts, the T. minuta oil extract and the neem oil (to concentrations of 2.5, 5.0, 10, 20 or 40\%); the diluted Tween 20 was also included in the control group.

Tick larvae aged 7-14 days were used in this study (FAO, 1984). The vials with the highest larval exclusion rate (90-100\%) were selected, and the larvae were placed in the center of a petri dish that was subsequently filled with water and soap to prevent their escape. The diluted plant crude extract $(3 \mathrm{~mL})$ was transferred to the petri dishes $(60 \times 15 \mathrm{~mm}$ in diameter), and $-300-500$ larvae were placed between two Whatman No. 1 papers and immersed for 10 minutes. Approximately 100 larvae were selected with a no. 4 paintbrush and gently transferred to clean filter paper packets.

The opened envelopes containing the tick larvae (treated and control) were folded with metallic clips and labeled with the appropriate identification markers (tested solution and concentration). The packets were placed in an incubator at $27 \pm 1.5^{\circ} \mathrm{C}$ and $70-80 \%$ relative humidity for 24 hours. The envelopes were opened 24 hours post-treatment $(\mathrm{PT})$ and observed using stereoscopy. The number of living larvae, the mortality and any other toxic effects were recorded. The larvae that were unable to walk were considered dead, as recommended by FAO (1984), and the corrected mortality was described using the following equation:

Corrected $=\frac{\% \text { Treated mortality }-\% \text { control mortality }}{100-\% \text { control mortality }} \times 100$

None of the control group bioassays showed a mortality rate of $>5 \%$.

\section{Results}

\section{Oil extract chromatography}

Table 1 shows the qualitative and quantitative analyses of a commercial sample of essential oil extract that was obtained from Tagetes minuta. Four main components are shown that represent more than $70 \%$ of the essential oil. They were identified as limonene (1), $\beta$-ocimene (2), dihydrotagetone (3) and tagetone (4) (Figure 1).

Table 1. The primary chemical composition of Tagetes minuta essential oil.

\begin{tabular}{lcc}
\hline \multicolumn{1}{c}{ Compound } & Retention time (min) & Area (\%) \\
\hline Limonene (1) & 9.52 & 6.96 \\
B-Ocimene (2) & 9.62 & 5.11 \\
Dihydrotagetone (3) & 9.89 & 54.21 \\
Tagetone (4) & 11.60 & 6.73 \\
\hline
\end{tabular}

Min - minutes. $\%$ percentage. 


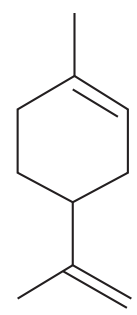

Limonene (1)

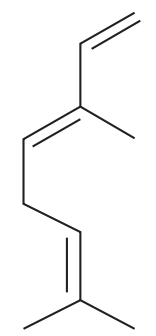

$\beta$ - Ocimene (2)

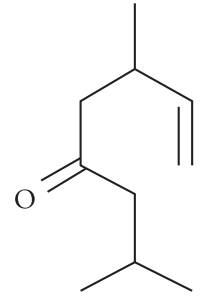

Dihydrotagetone (3)

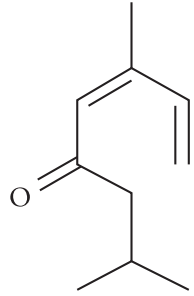

Tagetone (4)

Figure 1. Chemical structures of the compounds identified in the T. minuta essential oil.

Table 2. Efficacy of different concentrations of T. minuta oil extract against four tick species using the adult immersion test (AIT) and larval packet test (LPT). All protocols were performed in triplicate.

\begin{tabular}{lccccccccc}
\hline \multirow{1}{*}{ Tick species } & \multicolumn{10}{c}{ Concentrations $\%$} \\
\cline { 2 - 10 } & Test & $\mathbf{0 . 3}$ & $\mathbf{0 . 6}$ & $\mathbf{1 . 2 5}$ & $\mathbf{2 . 5}$ & $\mathbf{5}$ & $\mathbf{1 0}$ & $\mathbf{2 0}$ & $\mathbf{4 0}$ \\
\hline R.(B.)microplus & AIT & 5 & 5 & 9 & 22 & 45 & 79 & 95 & 100 \\
& LPT & 2 & 2 & 3.5 & 26.5 & 58 & 92.5 & 100 & 100 \\
\hline R. sanguineus & AIT & 2 & 3 & 12 & 27 & 65 & 89 & 100 & 100 \\
& LPT & 3 & 3 & 4 & 8 & 21 & 80 & 100 & 100 \\
\hline A. cajennense & AIT & 2 & 2 & 9 & 26 & 61 & 79 & 100 & 100 \\
& LPT & 3 & 8.5 & 9 & 16 & 45 & 62.5 & 95 & 100 \\
\hline A. miniatus & AIT & 5 & 12 & 31 & 69 & 97 & 100 & 100 & 100 \\
& LPT & 12 & 32 & 68 & 100 & 100 & 100 & 100 & 100 \\
\hline
\end{tabular}

$\%$ Percentage.

\section{NMR spectra}

The data from the ${ }^{1} \mathrm{H}$ and ${ }^{13} \mathrm{C}$ spectra of the primary constituents of the essential oil were compatible with those found in the literature (SINGH et al., 2002).

\section{Bioassay}

The effects of the T. minuta essential oil on the four tick species, as determined by the LPT (larval packet test), are described in Table 2. An efficacy of over $95 \%$ was observed against $A$. miniatus with a concentration of $2.5 \%$. A similar efficacy was reached against the Ixodidae ticks with a concentration of $20 \%$. In the AIT (adult immersion test) (Table 2), the essential oil showed 95\% efficacy against $A$. miniatus, and the ticks from the Ixodidae family had similar results as the LPT results.

No significant acaricidal activity was found against the $R$. (B.) microplus tick larvae by the commercial neem (Azadirachta indica) oil or the control sample by either the larval packet test (LPT) or the adult immersion test (AIT) (Table 3).

Four species of ticks were evaluated using the commercial acaricides that are available in the regional market; the data obtained in the assays for the larval packet test (LPT) and the adult immersion test (AIT) are shown in Table 4.

\section{Discussion}

T. minuta oil was shown to be very effective against both hard and soft ticks. Its efficacy at a concentration of $20 \%$ was comparable to the referenced conventional acaricides, and it reached over 95\% efficacy as required by the ministry of agriculture in Brazil.

According to the criteria of the Brazilian Ministry of Agriculture, Livestock and Supply (MAPA), new acaricides must provide an efficacy of at least $95 \%$ to become registered (BRASIL, 1997).

Plant extracts could provide a viable alternative to conventional acaricides because they are available locally at a low cost, and communities generally accept them. The concentration of $T$. minuta had an effect on the magnitude of the tick burden of the treated animals compared to the negative control when an infusion was used (MOYO et al., 2009). Ayacko (2008) reported an efficacy of $55 \%$ when using a decoction.

Importantly, the level of acaricidal activity of such compounds may vary depending on the plant species, growing conditions and the form of extraction, which directly affects the activity of essential oils. For this reason, it is necessary to conduct insightful research on the chemical composition of plant-derived substances and their effects. The process of extracting solvents, the applications of the techniques in the field, conservation and plant selectivity also need to be further evaluated (KNAAK; FIUZA, 2010)

Essential oils are distributed in a limited number of families, such as Asteraceae, and accumulate in all types of plant vegetative organs such as the flowers, leaves, barks, roots, rhizomes, fruits and seeds. In most cases, the biological function of the essential oil terpenoids remains obscure. It is conceivable, however, that they have an ecological role. The toxic mechanism of action of terpenoids has not been uncovered and is still unknown. Observations clearly suggest that the insecticidal activity and potency of monoterpenoids, as with the other insecticides, depend 
Table 3. Efficacy of commercial neem oil (Azadirachta indica) using the adult immersion test (AIT) and larval packet test (LPT). All protocols were performed in triplicate.

\begin{tabular}{lccccccccc}
\hline \multicolumn{1}{c}{ Tick Species } & \multicolumn{10}{c}{ Concentrations \% } \\
\cline { 2 - 10 } & Test & $\mathbf{0 . 3}$ & $\mathbf{0 . 6}$ & $\mathbf{1 . 2 5}$ & $\mathbf{2 . 5}$ & $\mathbf{5}$ & $\mathbf{1 0}$ & $\mathbf{2 0}$ & $\mathbf{4 0}$ \\
\hline R. (B.)microplus & AIT & 0.1 & 1.3 & 2.6 & 2 & 3 & 16 & 34 \\
& LPT & 0 & 0.3 & 1 & 1.2 & 2.8 & 19 & 36 & 55 \\
\hline R. sanguineus & AIT & 1.1 & 2 & 2.9 & 5.9 & 7.8 & 19 & 42 & 55 \\
& LPT & 0.3 & 0.9 & 1.4 & 2.9 & 6 & 15 & 39 & 45 \\
\hline A. cajennense & AIT & 0.6 & 2.1 & 3 & 3.4 & 5.3 & 16 & 38 & 41 \\
& LPT & 1.1 & 1.0 & 2.9 & 2.8 & 4 & 15 & 37 \\
\hline A. miniatus & AIT & 0.3 & 10 & 53 & 74 & 96 & 100 & 100 & 100 \\
& LPT & 9 & 26 & 61 & 79 & 100 & 100 & 100 & 100 \\
\hline
\end{tabular}

$\%$ Percentage.

Table 4. Efficacy values for commercial acaricides that were used at the commercially recommended concentrations for ticks and tested using the adult immersion test (AIT) and the larval packet test (LPT). All protocols were performed in triplicate.

\begin{tabular}{|c|c|c|c|c|c|c|c|}
\hline \multirow[t]{5}{*}{ Tick Species } & \multicolumn{7}{|c|}{ Chemical base } \\
\hline & \multirow[t]{4}{*}{ Test } & \multirow[t]{4}{*}{ Cypermethrin } & \multirow[t]{4}{*}{ Amitraz } & \multicolumn{4}{|c|}{ Cpt } \\
\hline & & & & Cpf & Ddvp & Ddvp & Ddvp \\
\hline & & & & $\mathrm{Ct}$ & $\operatorname{Dmt}\left(^{*}\right)$ & Cpt $(*)$ & Cpf $\left(^{*}\right)$ \\
\hline & & & & \multicolumn{4}{|c|}{ Bupi $(*)$} \\
\hline \multirow[t]{2}{*}{ R. (B.) microplus } & AIT & 14 & 39 & 98 & 28 & 16 & 100 \\
\hline & LPT & 36 & 26 & 100 & 35 & 28 & 100 \\
\hline \multirow[t]{2}{*}{ R. sanguineus } & AIT & 54 & 100 & 100 & 95 & 98 & 100 \\
\hline & LPT & 53 & 100 & 100 & 96 & 95 & 100 \\
\hline \multirow[t]{2}{*}{ A. cajennense } & AIT & 95 & 99 & 100 & 97 & 95 & 100 \\
\hline & LPT & 100 & 98 & 100 & 100 & 99 & 100 \\
\hline \multirow[t]{2}{*}{ A. miniatus } & AIT & 100 & 100 & 100 & 100 & 100 & 100 \\
\hline & LPT & 99 & 99 & 100 & 100 & 100 & 100 \\
\hline
\end{tabular}

(*) Associations. Abbreviations: Cypermethrine: Cpt; Chlorpyriphos: Cpf; Deltamethrin: Dmt; Citronella: Ct; Piperonylbutoxide: Bupi; Dichlorvos (DDVP): Ddvp.

on several factors, including dose, species, application surface, route of penetration, and method of application (ENAN, 2001).

There is evidence that the octopaminergic system is a target of several monoterpenoids, whether they are antagonists or agonists. Such monoterpenoids are highly selective to insects and are safer to the environment than the currently used insecticides, such as organophosphorus, carbamates and synthetic pyrethroids (ENAN, 2001).

Our results showed that the $A$. miniatus tick of the Argasidae family is at least five times more sensitive to essential oil than the ticks of the Ixodidae family. Thus, acaricide efficacy may vary by tick species. For the T. minuta essential oil to become an alternative acaricide, it is important to consider a formulation that is efficient and low cost. Plant products can be used in association with, or as replacements for, synthetic compounds. Therefore, follow-up studies are needed to validate this strategy. The advantage of using plant extracts may be slow resistance development because the extracts are usually composed of a mixture of different active agents with different mechanisms of action (OLIVO et al., 2009).

In this work, the effect of commercial neem oil was compared to $T$. minuta essential oil. At a $5 \%$ concentration, the T. minuta essential oil displayed only partial effectiveness against Ixodidae ticks. However, it achieved satisfactory results against $A$. miniatus.

Several studies have been conducted on the effect of neem extracts on cattle ticks, such as Amblyomma hebraeum, Rhipicephalus evertsi, Hyalomma truncatum, $R$. (B). decoloratus, $R$. (B.) microplus and Hyalomma anatolicum excavatum (WILLIAMS, 1993; KALAKUMAR et al., 2000; WEBB; DAVID, 2002).

A study by Benavides et al. (2001) showed that the treatment of naturally infested animals with a 5\% soapy, aqueous neem extract every 21 days was as effective against $R$. (B.) microplus as an amitraz-based commercial acaricide. The authors also demonstrated high in vitro efficacy (100\% inhibition of reproduction) by an ether extract, while alcohol extracts resulted in a $70 \%$ reduction in tick reproduction. The ethanol neem extracts were found to be effective in inhibiting oviposition. Abdel-Shafy and Zayed (2002) and Williams (1993) also concluded that neem oil could be used for tick control at economical concentrations of 1.6 to $3.2 \%$.

Souza et al. (2000) produced a concentrated emulsion of green fruits that was tested at concentrations of 0.25 and $0.5 \%$ and showed efficacies ranging from 46.7 to $82.6 \%$ and from 16.6 to $89.0 \%$, respectively. Broglio-Micheletti et al. (2010) analyzed the efficacies of a neem hexane extract and a $2 \%$ oil concentration against $R$. (B.) microplus and found in vitro efficacies of 73.2 and $65 \%$, respectively.

These results were found in different laboratories under different conditions, and the extract efficacies did not reach $95 \%$, which is required by the ministry of agriculture in Brazil.

The data from the AIT and LPT assays corroborated previous results that demonstrated the resistance of $R$. (B.) microplus. Only 
acaricides containing a mixture of cypermetrine, chlorpyriphos, citronella, piperonyl butoxide and a mixture of dichlorvos and clorpyrifos reached efficacies of over $95 \%$ against hard ticks (ANDREOTTI et al., 2011).

$A$. miniatus and $A$. cajennense ticks were sensitive to all of the tested chemicals, while $R$. sanguineus was only resistant to cypermethrin, an acaricide with wide commercial usage for this species. The data reinforce the notion that selective pressures through the use of different products on tick species lead to the low efficacy of each individual chemical in the control of these tick species.

The results of Knaak and Fiuza (2010) showed that the production of essential oil is viable and profitable. However, to obtain high quality products that are competitive in the market, incentives are necessary to develop modern techniques of cultivation, selection and plant breeding. Thus, we must continue to search for new control methods, such as the use of new compounds extracted from wild and cultivated medicinal plants, which can be used seamlessly with other methods. Ultimately, such new discoveries can lead to a reduction in the impact of chemical use.

\section{Conclusion}

This study shows that the essential oil of $T$. minuta has potential as a larval and adult acaricide for the control of four tick species in Brazil when compared to neem oil. In addition to being an effective larvicide, the oil is environmentally friendly; the active components are atoxic terpenoids, which are generally considered safe and are used in fragrances and as food additives.

The recommended concentration of $T$. minuta oil to be used as an acaricide is $20 \%$, and its use as a phytotherapeutic can contribute to the trend of integrating natural products into tick management in Brazil.

Future research efforts should be geared toward synthesizing chemical analogs of the active compounds of this essential oil and verifying their acaricidal activity.

\section{Acknowledgements}

The authors thank Embrapa Beef Cattle (Brazilian Agricultural Research Corporation), CNPq (National Council for Scientific and Technological Development) and Fundect-MS (State Research Foundation of Mato Grosso do Sul State) for their financial support.

\section{References}

Abdel-Shafy S, Zayed AA. In vitro acaricidal effect plant extract of neem seed oil (Azadirachata indica) on egg, immature and adult stages of Hyalomma anatolicum excavatum (Ixodoidea: Ixodidae). Vet Parasitol 2002; 106(1): 89-96. http://dx.doi.org/10.1016/S03044017(02)00023-7

Andreotti R, Guerrero FD, Soares MA, Barros JC, Miller RJ, León AP. Acaricide resistance of Rhipicephalus (Boophilus) microplus in State of Mato Grosso do Sul, Brazil. Rev Bras Parasitol Vet 2011; 20(2): 127133. PMid:21722487. http://dx.doi.org/10.1590/S198429612011000200007
Anuário da pecuária brasileira - ANUALPEC. São Paulo: Instituto FNP, 2009.

Ayacko W. Alternative method of tick control: The organic farmer. 2008. [cited 2012 Nov. 21]. Available from: http://www.biovision.ch/fileadmin/ $\mathrm{pdf} / \mathrm{d} /$ services/downloads/organic_farmer/org_farmer32_reduced.pdf

Barros-Battesti DM, Arzua M, Bechara GH. Carrapatos de Importância Médico-Veterinária da Região Neotropical: Um guia ilustrativo para identificação de espécies. São Paulo: Butantan; 2006.

Benavides OE, Hernandez MG, Romero NA, Castro AH, Rodriguez BJL. Preliminary evaluation of neem (Azadirachta indica) extracts as an alternative for cattle tick, Boophilus microplus control. Rev Colomb Entomol 2001; 27(1-2): 1-8.

Brasil. Ministério da Agricultura e do Abastecimento. Secretaria de Defesa Agropecuária. Portaria $n .48$ de 12 de maio de 1997. Regulamento técnico para licenciamento e/ou renovaçáo de licença de produtos antiparasitários de uso veterinário. Diário Oficial da União da República Federativa do Brasil, Brasília, DF, 16 maio 1997. Seção 1. p. 10165. [cited 2012 Nov. 21]. Available from: http://sistemasweb.agricultura.gov.br/sislegis/ action/detalhaAto.do?method=abrirArvoreTematicaNew.

Broglio-Micheletti SMF, Dias NS, Valente ECN, Souza LA, Lopes DOP, Santos JM. Ação de extrato e óleo de nim no controle de Rhipicephalus (Boophilus) microplus (Canestrini, 1887) (Acari: Ixodidae) em laboratório. Rev Bras Parasitol Vet 2010; 19(1): 46-50. PMid:20385059. http://dx.doi. org/10.4322/rbpv.01901008

Cen-Aguilar JF, Rodriguez-Vivas RI, Dominguez-Alpizar JL, Wagner GG. Studies on the effect on infection by Babesia sp. on oviposition of Boophilus microplus engorged females naturally infected in the Mexican tropics. Vet Parasitol 1998; 78(4): 253-257. http://dx.doi.org/10.1016/ S0304-4017(98)00148-4

Chamorro ER, Ballerini G, Sequeira AF, Velasco GA, Zalazar MF. Chemical composition of essential oil from Tagetes minuta L. leaves and flowers. J Argentine Chem Soc 2008; 96(1-2): 80-86.

Drummond RO, Ernst SE, Trevino JL, Gladney WJ, Graham OH. Boophilus annulatus and B. microplus: Laboratory tests of insecticides. J Econ Entomol 1973; 66(1): 130-133. PMid:4690254.

Enan E. Insecticidal activity of essential oils: octopaminergic sites of action. Comp Biochem Physiol C Toxicol Pharmacol 2001; 130(3): 325-337. http:// dx.doi.org/10.1016/S1532-0456(01)00255-1

Food and Agriculture Organization - FAO. Acaricide resistance. In: Food and Agriculture Organization - FAO. Ticks and tick-borne disease control: A practical field manual. Rome: FAO; 1984. vol. 1. Tick control, p. 246-299.

Grisi L, Massard CL, Moya-Borja GE. Impacto econômico das principais ectoparasitoses em bovinos no Brasil. A Hora Vet 2002; 21(125): 8-10.

Kalakumar B, Kumar HSA, Kumar BA, Reddy KS. Evaluation of custard seed oil and neem oil as acaricides. J Vet Parasitol 2000: 14(2): 171- 172.

Knaak N, Fiuza LM. Potencial dos óleos essenciais de plantas no controle de insetos e microrganismos. Neotrop. Biol.Conserv. 2010; 5(2):120-132. http://dx.doi.org/10.4013/nbc.2010.52.08

Labruna MB, Pereira MC. Carrapato em cães no Brasil. Clin Vet 2001; 30(1): 24-32.

Labruna MB, Home VSF, Heinemann MB, Ferreira Neto JS. Ticks (Acari: Ixodidae) associated with rural dogs in Uruará, Eastern Amazon, Brazil. J Med Entomol 2000; 37(5): 774-776. PMid:11004794. http:// dx.doi.org/10.1603/0022-2585-37.5.774 
Lisbôa RS, Guedes Junior DS, Silva FJM, Cunha NC, Machado CH, Fonseca AH. Alterações nos parâmetros hematológicos de Gallus gallus domesticus experimentalmente infectados por Borrelia anserina. Pesq Vet Bras 2008; 28(10): 527-532. http://dx.doi.org/10.1590/S0100736X2008001000014

Macêdo ME, Consoli RAGB, Grandi TSM, Anjos AMG, Oliveira AB, Mendes NM, et al. Screening of Asteraceae (Compositae) plant extracts for larvicidal activity against Aedes fluviatilis (Diptera: Culicidae). Mem Inst Oswaldo Cruz 1997; 92(4): 565-570. PMid:9361755. http://dx.doi. org/10.1590/S0074-02761997000400024

Moghaddam M, Omidbiagi R, Sefidkon F. Chemical composition of the essential oil of Tagetes minuta L. J Essent Oil Res 2007; 19(1): 3-4.

Moyo B, Masika PJ. Tick control methods used by resource-limited farmers and the effect of ticks in cattle in rural areas of the Eastern Cape Province, South Africa. Trop Anim Health Prod 2009; 41(4): 517-523. PMid:18704741. http://dx.doi.org/10.1007/s11250-008-9216-4

Moyo B, Masika PJ, Dube S, Maphosa V. An in-vivo study of the efficacy and safety of ethno-veterinary remedies used to control cattle ticks by rural farmers in the Eastern Cape Province of South Africa. Trop Anim Health Prod 2009; 41(7): 1569-1576. PMid:19396566. http://dx.doi. org/10.1007/s11250-009-9348-1

Olivo CJ, Heimerdinger A, Ziech MF, Agnolin CA, Meinerz GR, Both F, et al. Extrato aquoso de fumo em corda no controle do carrapato de bovinos. Cienc Rural 2009; 39(4): 1131-1135. http://dx.doi. org/10.1590/S0103-84782009000400026

Prakasa EVS, Syamasundar KV, Gopinath CT, Ramesh S. Agronomical and Chemical studies on Tagetes minuta grown in a red soil of a semiarid tropical region in India. J Essent Oil Res 1999; 11(2): 259-261. http:// dx.doi.org/10.1080/10412905.1999.9701127

Rosado-Aguilar JA, Aguilar-Caballero AJ, Rodríguez-Vivas RI, BorgesArgaez R, García-Vázquez Z, Méndez-González M, et al. Actividad ixodicida de extractos crudos de Diospyros anisandra contra larvas de
Rhipicephalus (Boophilus) microplus (Acari: ixodidae). Trop Subtrop Agroec 2008; 8(3): 297-301.

Sindicato Nacional da Indústria de produtos para Saúde Animal - SINDAN. Mercado veterinário por classe terapêutica e espécie animal 2009, [online] 2010. [cited 10 June 2011]. Available from: http:// www.sindan.org.br/sd/sindan/index/.

Singh B, Joshi VP, Kaul VK. Dihydrotagetone alcohol and a method for preparation thereof from Tagetes minuta oil. New Delhi: Council or Scientific and Industrial Research. US Patent 6.492.567; 2002.

Souza CAS, Avancini CAM, Wiest JA. Atividade antimicrobiana de Tagetes minuta L. Compositae (Chinchilho) frente a bactérias Grampositivas e Gram-negativas. BrazJ Vet Res Anim Sci 2000; 37(6): 429-433. http://dx.doi.org/10.1590/S1413-95962000000600001

Szabó MPJ, Cunha TM, Pinter A, Vicentini F. Ticks (Acari: Ixodidae) associated with domestic dogs in Franca region, São Paulo, Brazil. Exp Appl Acarol 2001; 25(10-11): 909-916. PMid:12455880. http://dx.doi. org/10.1023/A:1020433003028

Tomova BS, Waterhouse JS, Doberski J. The effect of fractionated Tagetes oil volatiles on aphid reproduction. Entomol Exp App 2005; 115(1): 153-159. http://dx.doi.org/10.1111/j.1570-7458.2005.00291.x

Webb EC, David M. The efficacy of neem seed extract (Azadirachta indica) to control tick infestation in Tswana, Simmentaler and Brahman cattle. South African J Anim Sci 2002; 32(1): 1-6. http://dx.doi. org/10.4314/sajas.v32i1.3784

Williams LAD. Adverse effects of Artocarpus altilis Park. and Azadirachta indica (A. Juss) on the reproductive physiology of the adult female tick, Boophilus microplus (Canest.). Invert Reprod Development 1993; 23(2-3): 159-164. http://dx.doi.org/10.1080/07924259.1993. 9672307 